\title{
His6-Tagged UL35 Protein of Duck Plague Virus: Expression, Purification, and Production of Polyclonal Antibody
}

\author{
Ming-Sheng Cai ${ }^{a}$ An-Chun Cheng ${ }^{a, b}$ Ming-Shu Wang ${ }^{a-c}$ Li-Chan Zhao ${ }^{a}$ \\ De-Kang Zhu ${ }^{\mathrm{a}, \mathrm{b}}$ Qi-Hui Luo ${ }^{\mathrm{b}}$ Fei Liub Xiao-Yue Chen ${ }^{\mathrm{a}}{ }^{\mathrm{b}}$ \\ ${ }^{a}$ Avian Disease Research Center, College of Veterinary Medicine, Sichuan Agricultural University, and \\ ${ }^{b}$ Key Laboratory of Animal Diseases and Human Health of the Sichuan Province, Yaan, and \\ ${ }^{c}$ College of Life Sciences and Technology, Southwest University for Nationalities, Chengdu, China
}

\section{Key Words}

Duck plague virus $\cdot$ Polyclonal antibody $\cdot$ Protein

expression $\cdot$ Protein purification $\cdot$ Recombinant protein •

UL35 gene

\begin{abstract}
Objective: Duck plague virus (DPV), the causative agent of duck plague (DP), is an alphaherpesvirus that causes an acute, febrile, contagious, and septic disease of waterfowl. UL35 protein (VP26) is a major capsid protein encoded by the UL35 gene, which is located in the unique long (UL) region of the DPV genome. To investigate the specific roles of VP26, the UL35 gene was amplified from the DPV DNA by polymerase chain reaction (PCR) and subcloned into pET-32a(+). Methods: The resultant prokaryotic expression vector, pET$32 \mathrm{a}(+) / \mathrm{UL} 35$, includes an amino-terminal His6 as a fusion partner. Escherichia coli BL21 (DE3) competent cells were transformed with the construct and protein expression was subsequently induced by the addition of isopropyl- $\beta$-Dthiogalactopyranoside to the culture medium. Protein lysates were submitted to SDS-PAGE to evaluate recombinant protein expression. Results: The band that corresponded to the predicted protein size $(33 \mathrm{kDa}$ ) was observed on the SDSPAGE gel. The recombinant His6-tagged VP26 fusion protein was expressed at a high level in an insoluble form (inclusion bodies) and constituted about $24 \%$ of the total cellular pro-
\end{abstract}

tein. Then, the fusion protein was purified to near homogeneity using single-step immobilized metal affinity chromatography on a nickel-nitrilotriacetic acid affinity resin, yielding about $620 \mathrm{mg}$ per liter culture. After purification, New Zealand white rabbits were immunized with purified His6-tagged VP26 in order to raise polyclonal antibody against this recombinant protein. Using the resultant sera, Western blot analysis showed that the recombinant protein was recognized by the polyclonal antibody. Conclusion: Thus, the polyclonal antibody prepared here may serve as a valuable tool to study the functional involvement of VP26 in the DPV life cycle.

Copyright $\odot 2009$ S. Karger AG, Basel

\section{Introduction}

Duck plague (DP), or duck virus enteritis, is an acute, febrile, contagious, and septic disease of waterfowl (duck, goose, and swan) caused by DP virus (DPV). The typical characteristics of DP are vascular injury, tissue hemorrhage and digestive tract and lymphatic organ damage. Duck-producing areas of the world where afflicted by the

The first four authors contributed equally to this work and should be considered as first author.

\section{KARGER}

Fax +41613061234 E-Mail karger@karger.ch www.karger.com
(C) 2009 S. Karger AG, Basel

0300-5526/09/0523-0141\$26.00/0

Accessible online at:

www.karger.com/int
An-Chung Cheng, Key Laboratory of Animal Diseases and Human Health of the

Sichuan Province Avian Disease Research Center

College of Veterinary Medicine, Sichuan Agricultural University

46 Xinkang Road, Yucheng District, Yaan 625014 (China)

Tel./Fax +86835288 5774, E-Mail chenganchun@vip.163.com 
DPV and have suffered considerable economic losses in the commercial duck industry due to high mortality, decreased egg production of ducks and the different lethality in wild waterfowl [1-9]. In China, the virulence of DPV has recently increased in geese but declined in ducks [10]. Presently, however, the molecular characteristics of DPV remain largely unknown.

DPV is composed of a linear, double-stranded DNA genome with $64.3 \%$ guanine-plus-cytosine content, which is higher than any other reported avian herpesvirus in the subfamily Alphaherpesvirinae [11]. Although DPV was previously grouped in the subfamily Alphaherpesvirinae $[12,13]$, it was classified as an unassigned virus in the Herpesviridae family according to the Eighth International Committee on Taxonomy of Viruses [14]. At present, studies on the genomic organization and nucleotide sequence of DPV lag behind other members of the Herpesviridae family because most of the previous studies have focused on the epidemiology and prevention of this disease. To the best of our knowledge, neither the molecular structure of the genome nor the restriction enzyme map of DPV DNA has been published up to now [4]. To date, the majority of reported DPV sequences are limited to single open reading frames (ORFs) in the unique long (UL) region, which includes UL6 [4, 15], UL25, UL26, UL26.5, UL27, UL28, UL29, and UL30 [16, 17]. However, no reports have been published concerning the DPV UL35 gene. Therefore, very little is known about the DPV UL35 gene or its encoding protein, VP26.

Recently, a DPV CHv-strain genomic library was constructed successfully for the first time [18] and the UL35 gene was discovered in our laboratory. In an effort to elucidate the function of VP26, we constructed a recombinant expression plasmid that drives expression of the DPV VP26 fused to His6. This plasmid was used to transform Escherichia coli BL21 (DE3) cells, which were subsequently induced to express the recombinant protein (His6-tagged VP26). His6-tagged VP26 was purified to near homogeneity using single-step immobilized metal affinity chromatography (IMAC) on a nickel-nitrilotriacetic acid $\left(\mathrm{Ni}^{2+}-\mathrm{NTA}\right)$ affinity resin. The purified protein was then used as an antigen for the production of polyclonal antibody specific for His6-tagged VP26.

\section{Materials and Methods}

Virus, Strains, Plasmids, Enzymes, and Other Materials

The DPV CHv strain is a high-virulence field strain of DPV that was isolated and preserved in the authors' laboratory. E. coli strain $\mathrm{DH} 5 \alpha$, E. coli BL21 (DE3), cloning vector pMD18-T, and expression vector pET-32a(+) were purchased from Invitrogen. Yeast extract and tryptone for bacterial medium preparation were obtained from Promega. Fetal bovine serum (FBS), antibiotics, and isopropyl- $\beta$-D-thiogalactopyranoside (IPTG) were bought from Novagen. Restriction enzymes, DNA ligase, Ex Taq DNA polymerase, DNA molecular weight markers, and protein molecular weight markers were obtained from TaKaRa; other reagents were offered by the Avian Diseases Research Center of the Sichuan Agricultural University. All reagents were of the highest purity that was commercially available. Purification of His-tagged protein was performed on $\mathrm{A} \mathrm{Ni}^{2+}$-NTA resin (Qiagen). Here, E. coli strain $\mathrm{DH} 5 \alpha$ was used as the cloning host for the UL35 gene encoding VP26 because of its very high transformation efficiency. For the expression of His6-tagged VP26, the E. coli strain BL21 (DE3) was used. This strain has the advantage of being deficient in both the lon and ompT proteases and harbors the T7 bacteriophage RNA polymerase gene, which permits the specific expression of heterologous genes driven by the T7 promoter [19-21].

\section{Preparation of DPV DNA}

DPV was propagated in primary duck embryo fibroblasts that were grown in Dulbecco's MEM (D-MEM; Gibco-BRL) supplemented with $10 \% \mathrm{FBS}$ at $37^{\circ}$. For virus infection, D-MEM supplemented with 2-3\% FBS was used. Viral particles were harvested when the cytopathic effect reached $75 \%$. Cell lysates containing DPV were subjected to three freeze-thaw cycles and were then stored at $-70^{\circ}$ until use. The presence of DPV was confirmed by both electron microscopy and polymerase chain reaction (PCR), as described previously $[15,22]$.

To isolate the nuclear DPV DNA, 5-10 ml DPV-containing cell lysate was centrifuged at 5,000 rpm for $10 \mathrm{~min}$ at $4^{\circ}$. The supernatant was decanted, and the cell pellet was resuspended in $2-5 \mathrm{ml}$ NET (0.1 M NaCl, 1.0 mM EDTA, pH 8.0, and 10 mM Tris, pH 8.0). The cell suspension was centrifuged at $5,000 \mathrm{rpm}$ for $10 \mathrm{~min}$ at $4^{\circ}$. Then, the supernatant was discarded and the pellet was redissolved in $750 \mu \mathrm{l} \mathrm{NET,} 7.5 \mu \mathrm{l}$ proteinase K (10 mg stock), and $50 \mu \mathrm{l}$ of $15 \%$ sarcosyl. The sample was incubated at $37^{\circ}$ to promote proteinase $\mathrm{K}$ activity. The cell lysate was then centrifuged at $12,000 \mathrm{rpm}$ for $30 \mathrm{~min}$ at $4^{\circ}$. The nuclear DNA-containing supernatant was transferred to a fresh tube and submitted to RNase treatment at $37^{\circ}$ for 1 or $2 \mathrm{~h}$. DNA was extracted first with one volume of phenol (750 $\mu \mathrm{l})$, then with phenol/choloroform/isoamyl alcohol (25:24:1), and finally with chloroform. DNA was precipitated with two volumes of prechilled absolute ethanol and stored at $-20^{\circ}$ for future use.

Primer Design and PCR Amplification of the DPV UL35 Gene The full-length DPV UL35 gene (GenBank accession No. EF643558) is composed of 354 base pairs and contains a complete theoretical ORF for a 117-residue UL35-like protein. The primers for the PCR-based amplification of this ORF were designed using the biological software Oligo6.0 and Primer5.0 and were synthesized by TaKaRa, with an expected amplified fragment of $354 \mathrm{bp}$. The upstream primer 5'GGATCCATGTCTAATTCTGGAGGTTCA anneals with the first 21 nucleotides of the UL35 sequence and introduces an upstream BamHI restriction site (underlined). The downstream primer 5'AAGCTTTTATCGCTGATCGTCTGG is complementary to the final 18 nucleotides of the UL35 sequence and introduces a HindIII restriction site (underlined). These restriction sites were included to facilitate the subsequent cloning procedure. 
The UL35 gene was amplified by PCR from the genome of the DPV CHv strain, using DNA, which was purified as described above, as the template. PCR was performed in a $25-\mu l$ reaction volume, as described previously [22]. PCR amplifications were carried out using the following reaction cycles in a commercial PCR system (2700; GeneAmp): initial denaturation at $95^{\circ}$ for 5 min followed by 32 consecutive cycles of denaturation at $94^{\circ}$ for $50 \mathrm{~s}$, annealing for $40 \mathrm{~s}$ at $56^{\circ}$, and extension at $72^{\circ}$ for $40 \mathrm{~s}$, and then a final extension at $72^{\circ}$ for $10 \mathrm{~min}$, using Ex Taq DNA polymerase. The amplified product (354 bp) was analyzed by electrophoresis on a $2 \%(\mathrm{w} / \mathrm{v})$ agarose gel stained with $0.5 \mu \mathrm{l} / \mathrm{ml}$ ethidium bromide. After the PCR-amplified product had been validated as the intended product, it was purified using a PCR gel purification kit (Qiagen) according to the manufacturer's instructions. The purified PCR product was then submitted to ligation into a pMD18-T vector.

\section{Construction of Cloning Plasmid pMD18-T/UL35}

The purified PCR product was digested with BamHI and HindIII restriction enzymes, purified and ligated into the correspondingly digested cloning vector pMD18-T at $16^{\circ}$ overnight using T4 DNA ligase to generate a recombinant cloning plasmid named pMD18-T/UL35 (fig. 1), using standard cloning methods [23]. Competent E. coli DH5 $\alpha$ cells were transformed with the ligation mixture by the heat shock method and used for propagation of the cloning plasmid. The transformants were cultured at $37^{\circ}$ on Luria-Bertani (LB) solid medium (1.0\% sodium chloride, $1.0 \%$ tryptone, $0.5 \%$ yeast extract, and $1.5 \%$ agar) for $16 \mathrm{~h}$ and in LB liquid medium (as above but without agar) at $37^{\circ}$ for $12 \mathrm{~h}$, supplemented with $100 \mu \mathrm{g} / \mathrm{ml}$ ampicillin when plasmid maintenance was required. After mini-scale isolation of plasmid DNA using the modified alkaline lysis method [24], the presence of the appropriate insert in the obtained plasmid was verified by PCR and restriction analysis. One clone was then selected and sent to TaKaRa for sequencing.

\section{Construction of the pET-32a(+)/UL35 Expression Plasmid}

After its sequence had been confirmed, pMD18-T/UL35 was digested with BamHI and HindIII restriction enzymes and submitted to electrophoresis through a $1 \%$ agarose gel, then the DNA band corresponding to the digested insert (ORF) was cut and purified from the agarose gel and directionally ligated into the previously BamHI-/HindIII-digested and dephosphorylated expression vector $\mathrm{pET}-32 \mathrm{a}(+)$, downstream of the T7 Lac promoter and His6 tag and upstream of the T7 terminator, to construct the recombinant prokaryotic expression vector $\mathrm{pET}-32 \mathrm{a}(+) / \mathrm{UL} 35 \mathrm{using}$ T4 DNA ligase (fig. 2). Cloning at the BamHI site in pET-32a $(+)$ results in a His6 fusion to the N-terminus of the cloned gene. This fusion tag permits purification of the produced protein by metal chelate chromatography on a nitrilotriacetic acid agarose matrix charged with nickel ions. The ligation mixture was transformed into competent $E$. coli $\mathrm{DH} 5 \alpha$ cells. Positive clones with a gene insert in the plasmid were first evaluated by PCR and then reconfirmed by restriction digestion and DNA sequencing. Each identified positive colony was grown in LB medium containing ampicillin $(100 \mu \mathrm{g} / \mathrm{ml})$. The plasmid pET-32a(+)/UL35 was isolated from the bacterial cells and used to transform the competent $E$. coli strain BL21 (DE3) cells for the purpose of recombinant protein expression.

His6-Tagged UL35 Protein of Duck Plague Virus

\section{Expression of the Recombinant Protein}

For recombinant protein expression, E. coli strain BL21 (DE3) cells were transformed with the plasmid pET-32a(+)/UL35 and selected on LB solid medium containing ampicillin $(100 \mu \mathrm{g} / \mathrm{ml})$. The transformants were inoculated into $5 \mathrm{ml}$ of culture medium in test tubes and allowed to grow overnight at $37^{\circ}$ with constant agitation $(200 \mathrm{rpm})$. These cultures were used to inoculate $100 \mathrm{ml} \mathrm{LB}$ containing ampicillin $(100 \mu \mathrm{g} / \mathrm{ml})$ and were submitted to vigorous shaking in a fermenter. When the cultures initially reached logarithmic phase (at $\mathrm{OD}_{600}$ of 0.5-0.6), expression of the recombinant fusion protein, His6-tagged VP26, was induced by the addition of IPTG (final concentration $1.0 \mathrm{mM}$ ) with further growth at $37^{\circ}$ for $4 \mathrm{~h}$. After induction, the cells were harvested by centrifugation at $6,000 \mathrm{rpm}$ for $10 \mathrm{~min}$ at $4^{\circ}$ and lysed in $5 \times$ SDS-PAGE loading buffer $(0.313 \mathrm{M}$ Tris-HCl, pH 6.8, 50\% glycerol, 10\% SDS, and $0.05 \%$ bromophenol blue, with $100 \mathrm{~mm}$ DTT). Then, the cell lysates were boiled for $15 \mathrm{~min}$, centrifuged at 12,000 rpm for $10 \mathrm{~min}$, submitted to $12 \%$ SDS-PAGE, and then analyzed by Coomassie brilliant blue R-250 staining. Briefly, the gel was stained with Coomassie brilliant blue R-250 overnight and destained in 6\% acetic acid until a clear background was reached to assess the expression level of the recombinant fusion protein by densitometric scanning using Bandscan 4.5 software [25]. The uninduced control culture and the vector control culture were analyzed in parallel.

To increase the production of the recombinant protein, culture conditions for expression were optimized in terms of different temperatures $\left(30,34\right.$, and $\left.37^{\circ}\right)$, concentrations of IPTG $(0,0.2$, 0.4. $0.6,0.8,1.0,1.2,1.5$, and $2.0 \mathrm{mM}$ ), and durations of induction $(0,1,2,3,4,5,6$, and $7 \mathrm{~h}$, and overnight). Protein expression was assessed by SDS-PAGE, as described above.

For the initial experiments, which were designed to determine the solubility of the recombinant protein, log phase cultures were induced with $1 \mathrm{mM} \mathrm{IPTG}$ for $5 \mathrm{~h}$ at $34^{\circ}$, and approximately $4 \mathrm{~g}$ of wet weight cells from 1 liter of culture were harvested by centrifugation at $6,000 \mathrm{rpm}$ for $10 \mathrm{~min}$. The cells were left overnight at $-20^{\circ}$ and were then suspended in $20 \mathrm{ml}$ lysis buffer of $20 \mathrm{~mm}$ Tris$\mathrm{HCl}$ buffer ( $\mathrm{pH}$ 8.0) containing $100 \mathrm{~mm} \mathrm{NaCl}, 1.0 \mathrm{~mm}$ phenylmethyl sulfonylfluoride (PMSF), and $1.0 \mathrm{mg} / \mathrm{ml}$ lysozyme. The suspension was incubated for $30 \mathrm{~min}$ at $4^{\circ}$ with stirring and was then pulse sonicated on ice (30 s working and $30 \mathrm{~s}$ resting on ice, Vibrocell VCX600 sonicator, $600 \mathrm{~W}$ max; Sonics and Materials) until the sample was clear. Sonication was performed to release intracellular proteins. The resulting cell lysate was centrifuged at $12,000 \mathrm{rpm}$ for $30 \mathrm{~min}$. The clear supernatant (soluble fraction) was collected and the remaining pellets (insoluble fraction), which contained the inclusion bodies, were dissolved in deionized water and stored at $-20^{\circ}$ until use. Soluble and insoluble fractions were then analyzed in parallel by $12 \%$ SDS-PAGE.

\section{Purification of the Recombinant Protein}

The pellets of the insoluble fraction (crude extract) were resuspended in extraction buffer $(0.5 \mathrm{M} \mathrm{NaCl}, 2 \mathrm{M}$ urea, $1 \mathrm{mM}$ DTT, $2 \%$ Triton X-100, and $20 \mathrm{~mm}$ Tris- $\mathrm{HCl}, \mathrm{pH} 7.9$ ), sonicated for $30 \mathrm{~s}$ at $4^{\circ}$, and centrifuged at $15,000 \mathrm{rpm}$ for $30 \mathrm{~min}$. The pellets were washed twice with washing buffer $(0.5 \mathrm{M} \mathrm{NaCl}, 2 \mathrm{M}$ urea, $20 \mathrm{mM}$ Tris- $\mathrm{HCl}, \mathrm{pH}$ 7.9), resuspended in regeneration buffer $(0.5 \mathrm{M}$ $\mathrm{NaCl}, 6 \mathrm{M}$ urea, $20 \mathrm{~mm}$ Tris- $\mathrm{HCl}, \mathrm{pH}$ 7.9) and incubated at room temperature $\left(25^{\circ}\right)$ for $30 \mathrm{~min}$. The incubated mixture was then centrifuged at 15,000 rpm for $10 \mathrm{~min}$, and the resultant supernatant was submitted to further purification. 


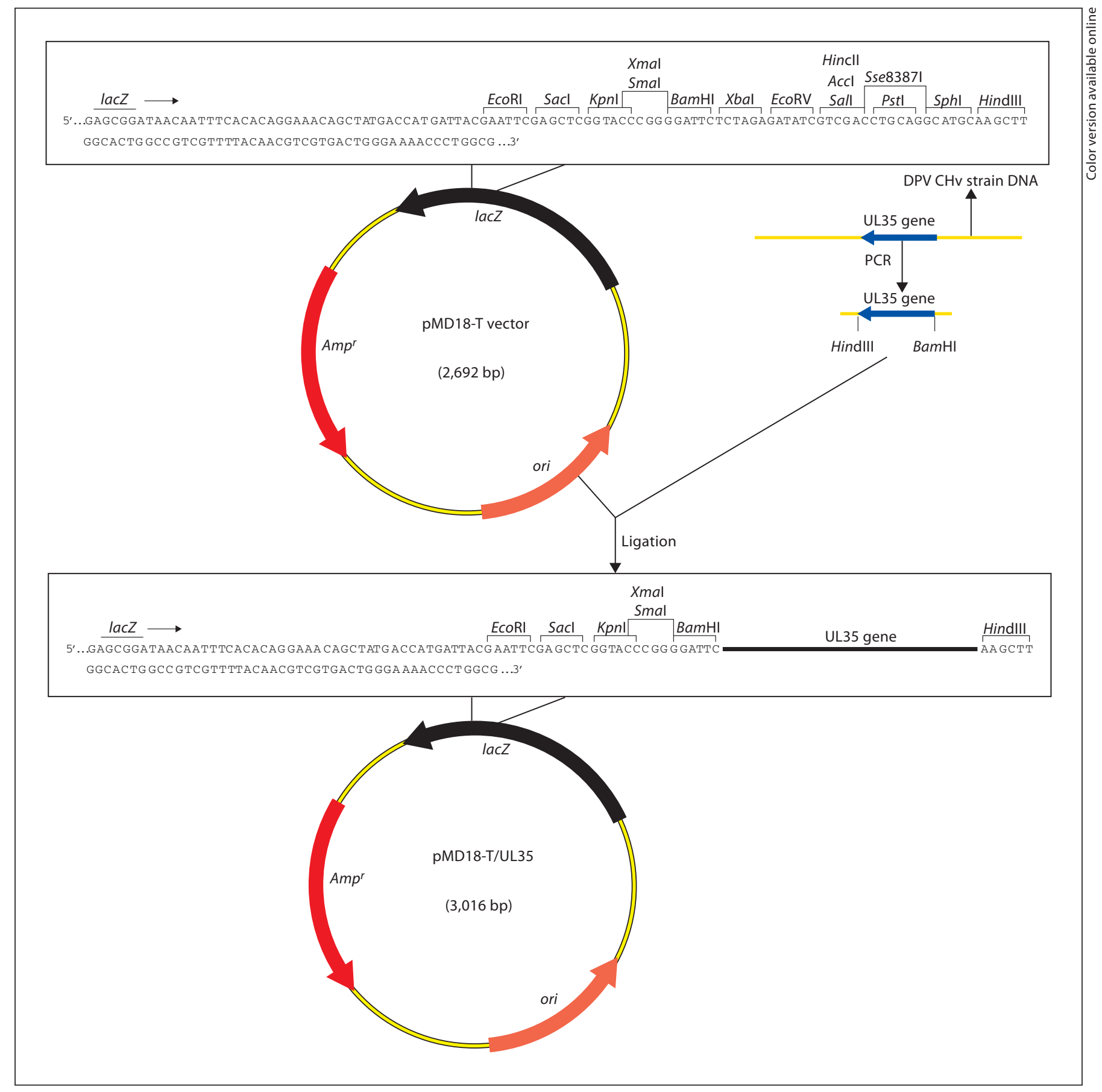

Fig. 1. Schematic diagram of the UL35 ORF cloned into the pMD18-T cloning vector.

The recombinant His-tagged VP26 was purified from the supernatant obtained above by IMAC on $\mathrm{Ni}^{2+}$-NTA affinity resin following the manufacturer's instructions with modifications. A glass column ( $20 \mathrm{ml}$ capacity) was packed with $\mathrm{Ni}^{2+}-\mathrm{NTA}$ resin matrix. The column was equilibrated with 4 bed volumes of IMAC buffer (20 mM Tris-HCl, pH 8.0, $500 \mathrm{mM} \mathrm{NaCl}, 0.5 \mathrm{mM}$
PMSF, and $10 \mathrm{~mm}$ imidazole). The chromatography flow rate, which was driven by gravity, was $0.5 \mathrm{ml} / \mathrm{min}$. The supernatant (crude extract) was loaded onto the $\mathrm{Ni}^{2+}$-NTA agarose resin column preequilibrated with IMAC buffer. The column was washed successively with 3 bed volumes of IMAC buffer and 5 bed volumes of IMAC buffer containing $20 \mathrm{~mm}$ imidazole. The protein 


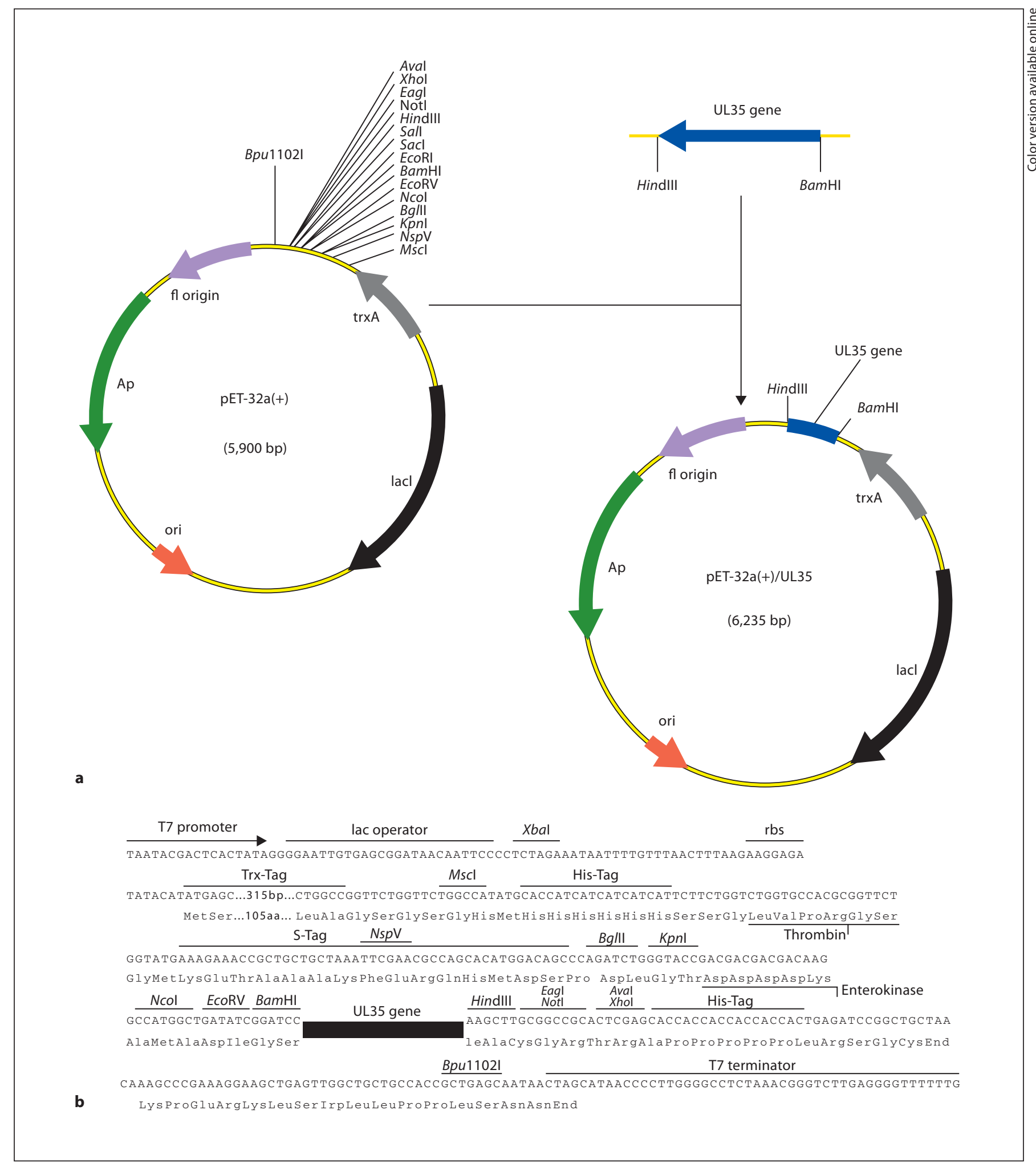

Fig. 2. Construction of the recombinant expression plasmid pET-32a(+)/UL35. a Schematic diagram of the UL35 ORF cloned into the pET-32a(+) expression plasmid. b Detailed structural features of the constructed recombinant expression plasmid pET-32a(+)/UL35. The recombinant protein consisted of Trx, His tag, thrombin cleavage site, $\mathrm{S}$ tag, and enterokinase cleavage site. 


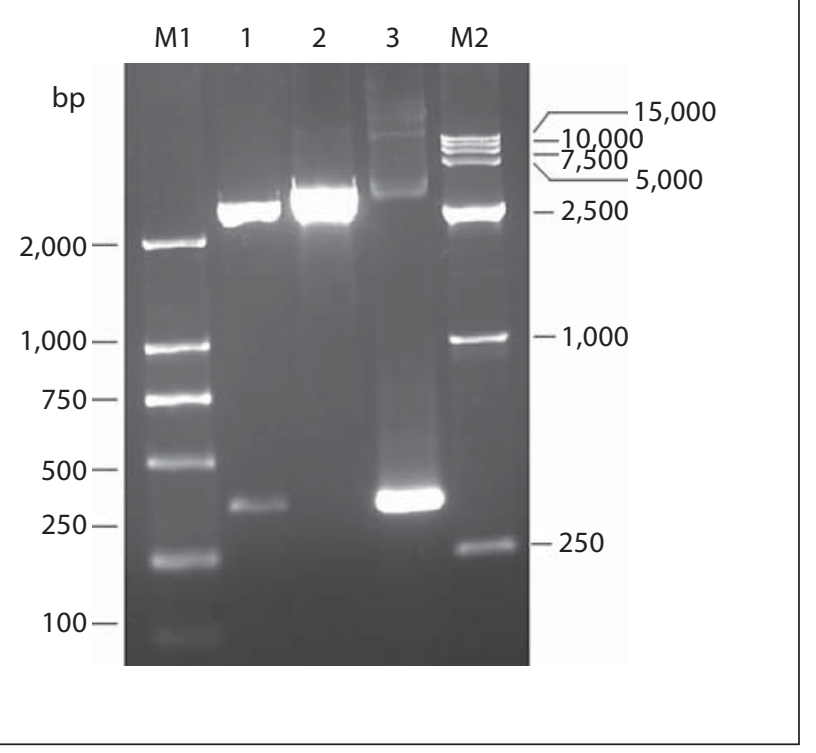

Fig. 3. Characterization of the recombinant plasmid pMD18-T/ UL35 by restriction digestion and PCR-based amplification. M1 = DNA marker of 2,000 bp; $1=$ pMD18-T/UL35 digested with BamHI and HindIII; 2 = pMD18-T/UL35 digested with BamHI; 3 = product amplified from pMD18-T/UL35 (ORF $354 \mathrm{bp}$ ); M2 = DNA marker of 15,000 bp.

impurities devoid of histidine tails were removed from the agarose resin at a flow rate of $2.0 \mathrm{ml} / \mathrm{min}$ at $4^{\circ}$. The fusion protein was eluted with IMAC buffer containing $8 \mathrm{M}$ urea and $100 \mathrm{~mm}$ imidazole at a flow rate of $1.0 \mathrm{ml} / \mathrm{min}$ at $4^{\circ}$. Five-milliliter fractions were collected and analyzed by SDS-PAGE to identify the fusion protein and to assess the level of homogeneity. The protein concentration was estimated by the method of Bradford using bovine serum albumin (BSA) as the standard (0-12 $\mu \mathrm{g})$ [26]. Fractions that contained the purified His6-tagged VP26, which was in a denatured state, were pooled and dialyzed against $\mathrm{PBS}$ buffer (10 $\mathrm{mM} \mathrm{Na}_{2} \mathrm{HPO}_{4}, 1.8 \mathrm{mM} \mathrm{KH} \mathrm{PO}_{4}$, pH 7.4, $140 \mathrm{mM} \mathrm{NaCl}$, and $2.7 \mathrm{mM} \mathrm{KCl}$ ) containing $1 \mathrm{mM}$ PMSF with progressively lower concentrations of urea $(4,2$, and $0 \mathrm{M})$ for a total time of $72 \mathrm{~h}$. The purified recombinant protein was stored at $4^{\circ}$ for use within 1 week or at $-70^{\circ}$ for use after a longer time.

\section{Production of Polyclonal Antibody against the Recombinant}

\section{Protein}

The purified recombinant protein was used for raising antibody in New Zealand white rabbits. Blood $(1.5 \mathrm{ml})$ was collected prior to immunization by bleeding the rabbits from the marginal vein of the ear. This serum served as a negative control. Afterwards, the rabbits were then intradermally injected with a mixture of $500 \mu \mathrm{g}$ of purified recombinant protein mixed with an equal volume of Freund's complete adjuvant (Promega) on the back and proximal limbs $(100 \mu \mathrm{l} / \mathrm{site})$. After 2 weeks, the rabbits were twice boosted intramuscularly with $500 \mu \mathrm{g}$ of purified re- combinant protein and incomplete Freund's adjuvant at a 1-week interval. Subsequently, each rabbit was intravenously immunized with $100 \mu \mathrm{g}$ of the purified recombinant protein. Two weeks after the last injection, the rabbit with the best reactivity toward His6tagged VP26 was sacrificed, and the antiserum was harvested from the arteriae carotis and stored at $-80^{\circ}$ until further use.

\section{Purification of the Antiserum}

First, the rabbit IgG fraction was precipitated from the harvested rabbit polyclonal antiserum by ammonium sulfate precipitation. Then, by using a DEAE-Sepharose column (Bio-Rad), the IgG fraction was purified by ion exchange column chromatography following the manufacturer's instructions. The purified IgG fraction was analyzed by $12 \%$ SDS-PAGE.

\section{Western Blot Analysis}

To characterize the antigenicity of the recombinant fusion protein, His6-tagged VP26, Western blot analysis was performed according to a standard procedure [27] using the purified rabbit anti-His6-tagged VP26 IgG. After the proteins had been separated by $12 \%$ SDS-PAGE, the gel was immersed in transfer buffer (0.24\% Tris- $\mathrm{HCl}, 1.153 \%$ glycine, and $15 \%$ methanol, $\mathrm{pH} 8.8)$ and electrophoretically transferred onto nitrocellulose membrane (Bio-Rad) preequilibrated in transfer buffer using a Mini Trans Blot electrophoretic transfer cell (Bio-Rad) at $80 \mathrm{~V}$ for $1.5 \mathrm{~h}$. The membrane was incubated in blocking buffer (5\% BSA in PBS buffer) for $1 \mathrm{~h}$ at $37^{\circ}$ or overnight at $4^{\circ}$. After three washes $(10 \mathrm{~min}$ each) with $1 \times$ PBS buffer, the membrane was incubated with rabbit anti-His6-tagged VP26 IgG at a dilution of 1:100 with 1\% BSA in PBS overnight at $4^{\circ}$. The membrane was then washed three times with $1 \times$ PBS containing $0.1 \%$ Tween-20 (PBST), and was further incubated with horseradish peroxidase-labeled goat antirabbit IgG (Boster) at a dilution of 1:5,000 for $1 \mathrm{~h}$ at $37^{\circ}$. The membrane was then washed three times with PBST and three times with PBS and developed with diaminobenzidine substrate buffer. Color development was terminated by thorough washing in distilled water.

\section{Results and Discussion}

\section{Gene Amplification, Cloning, and Sequencing}

On the basis of the constructed DPV CHv-strain genomic library [18], primers were designed to amplify the UL35 gene using DPV DNA as a template. BamHI and HindIII sites were designed in the primers to facilitate subsequent cloning. The PCR product (354 bp; data not shown) was digested with $\mathrm{Bam} \mathrm{HI}$ and HindIII restriction enzymes and the ORF was inserted into the vector pMD18-T between the BamHI and HindIII sites to construct the cloning vector pMD18-T/UL35. Then, the recombinant plasmid was confirmed by DNA sequencing and restriction digestion (fig. 3). The sequencing result showed that there were no nucleotide errors in the synthetic UL35 gene fragment (data not shown). 


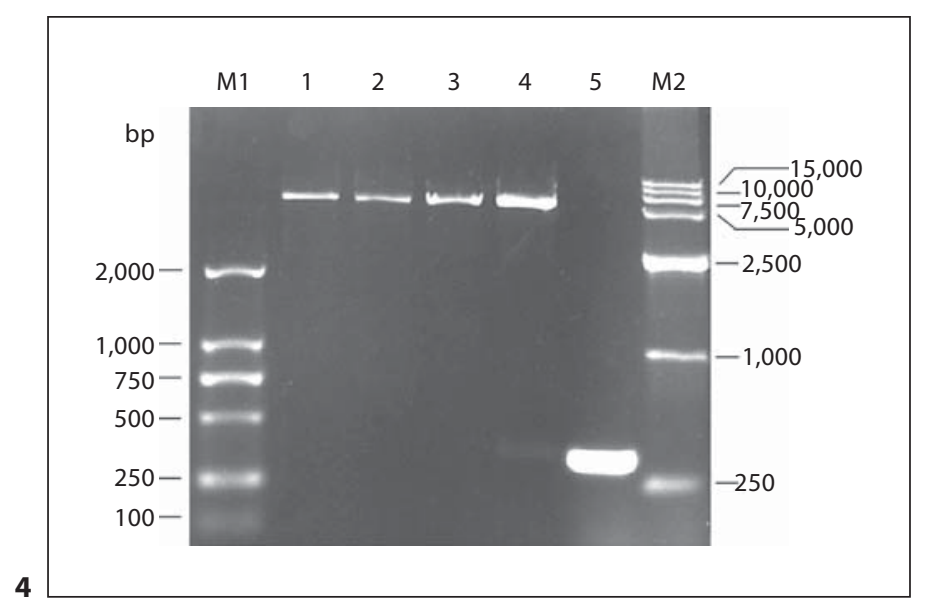

Fig. 4. Characterization of the recombinant plasmid pET-32a(+)/ UL35 by restriction digestion and PCR-based amplification. $\mathrm{M} 1=$ DNA marker of 2,000 bp; $1=$ pET-32a $(+) ; 2=$ pET-32a $(+)$ digested with BamHI and HindIII; $3=$ pET-32a $(+) / \mathrm{UL} 35$ digested with BamHI; $4=$ pET-32a(+)/UL35 digested with BamHI and HindIII; 5 = product amplified from pET-32a(+)/UL35; M2 = DNA marker of 15,000 bp.

Fig. 5. Expression analysis and optimization of the expression conditions of the His6-tagged VP26 fusion protein. a Coomassiestained SDS-PAGE gel (12\%) analysis for the expression and optimization of the temperature for His6-tagged VP26 fusion protein. $\mathrm{M}=$ Protein molecular weight marker; 1 = total protein from E. coli $\mathrm{BL} 21 / \mathrm{pET}-32 \mathrm{a}(+)$ before induction; 2 = total protein from E. coli $\mathrm{BL} 21 / \mathrm{pET}-32 \mathrm{a}(+)$ after induction; 3 = total protein from E. coli $\mathrm{BL} 21 / \mathrm{pET}-32 \mathrm{a}(+) / \mathrm{UL} 35$ before induction; 4,6 and $8=$ soluble fractions of total protein from $E$. coli BL21/pET-32a(+)/UL35 after induction at 30,34 , and $37^{\circ}$, respectively; 5,7 and $9=$ insoluble fractions (inclusion bodies) of total protein from $E$. coli $\mathrm{BL} 21 / \mathrm{pET}-32 \mathrm{a}(+) / \mathrm{UL} 35$ after induction at 30,34 and $37^{\circ}$, respectively. $\mathbf{b}$ SDS-PAGE analysis for optimization of the concentration of IPTG for His6-tagged VP26 fusion protein expression. $\mathrm{M}=$ protein molecular weight marker; $1-9=$ total protein from $E$. coli BL21/pET-32a(+)/UL35 after induction with the following concentrations of IPTG: $0,0.2,0.4 .0 .6,0.8,1.0,1.2,1.5$, and $2.0 \mathrm{mM}$, respectively, at $34^{\circ}$. c SDS-PAGE analysis for optimization of the duration of induction for His6-tagged VP26 fusion protein expression. $\mathrm{M}=$ protein molecular weight marker; $1-9$ = total protein from E. coli BL21/pET-32a(+)/UL35 after induction with IPTG (1.0 mM) for $0,1,2,3,4,5,6$, and $7 \mathrm{~h}$ and overnight, respectively, at $34^{\circ}$. Since an equal amount of sample was loaded into each lane, it is possible to compare the expression levels among lanes. The highest level of expression was observed for $5 \mathrm{~h}$ after induction at $34^{\circ}$ with $1 \mathrm{~mm}$ IPTG. Arrows indicate the position of the fusion protein.

\section{Construction of the Expression Plasmid}

The prokaryotic expression vector pET-32a(+), which features a high stringency T7 lac promoter, His6 tag, and T7 terminator, has been recognized as one of the most powerful tools for producing recombinant proteins in
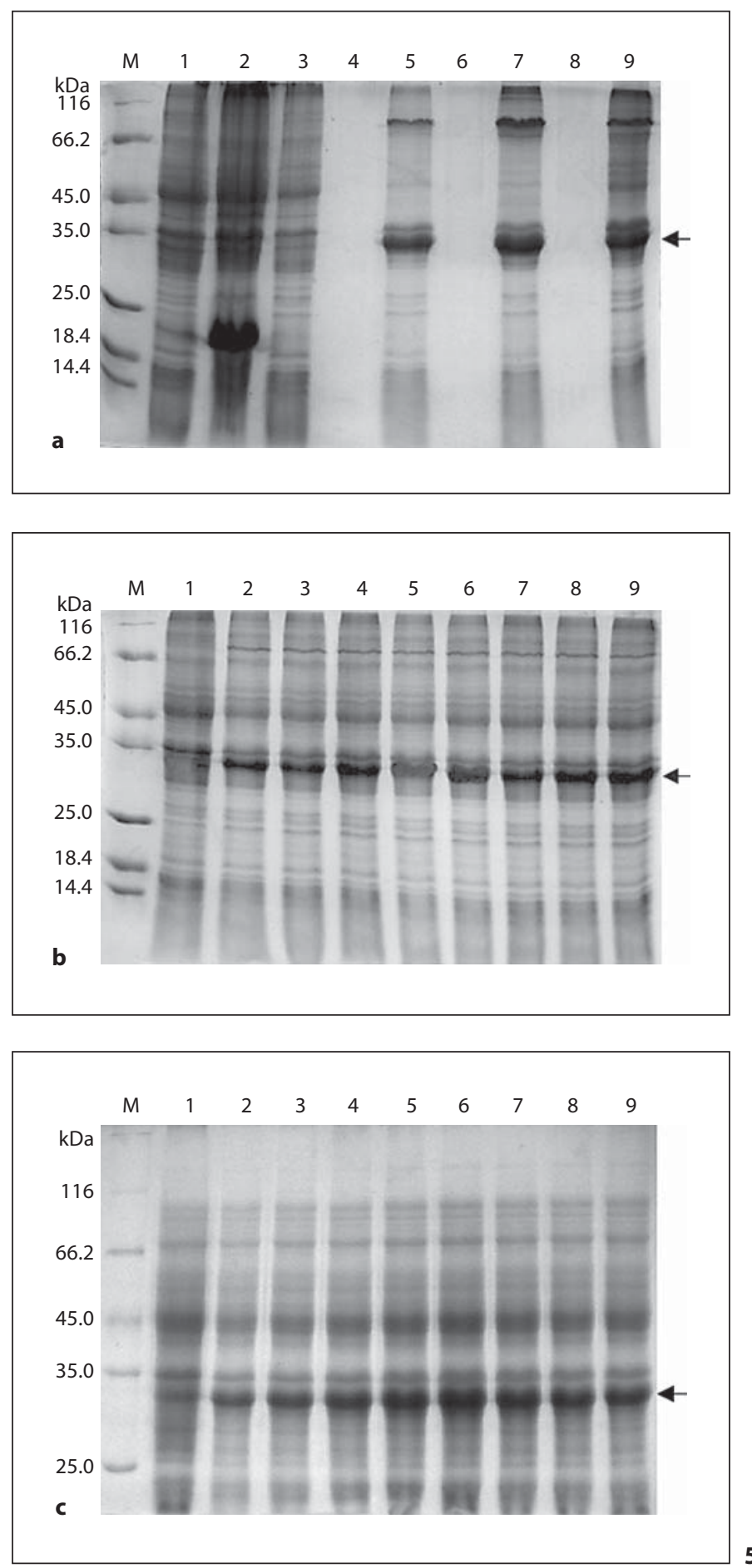

E. coli [28]. The UL35 gene fragment, which was obtained by digestion of pMD18-T/UL35 with BamHI and HindIII, was directionally inserted downstream of the His6-tag sequence in the pET-32a $(+)$ plasmid to construct the expression plasmid pET-32a(+)/UL35. The initial transfor- 


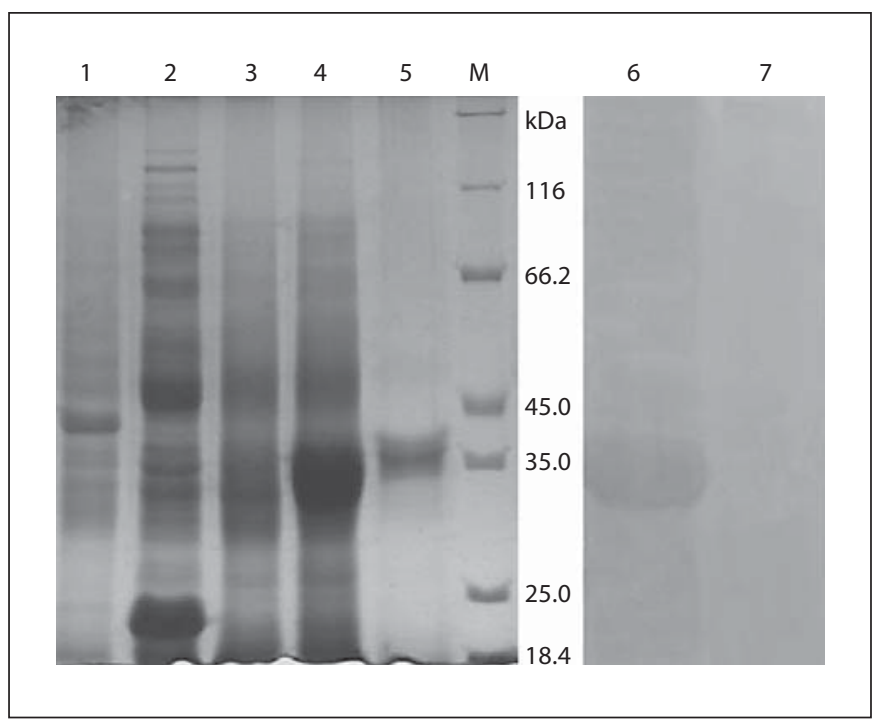

Fig. 6. Purification and Western blot analysis of the purified recombinant His6-tagged VP26 fusion protein. $\mathrm{M}=$ Protein molecular weight marker; 1 = total protein from E. coli BL21/pET$32 \mathrm{a}(+)$ before induction; 2 = total protein from $E$. coli BL21/pET$32 \mathrm{a}(+)$ after induction; 3 = total protein from $E$. coli BL21/pET$32 \mathrm{a}(+) / \mathrm{UL} 35$ before induction; $4=$ total protein from $E$. coli BL21/ pET-32a $(+) / \mathrm{UL} 35$ after IPTG induction $(1.0 \mathrm{mM})$ at $34^{\circ}$ for $5 \mathrm{~h}$; $5=$ purified recombinant His6-tagged VP26 fusion protein using a single chromatographic step of IMAC on $\mathrm{Ni}^{2+}$-NTA agarose; $6=$ rabbit anti-His6-tagged VP26 IgG reacted with His6-tagged VP26; 7 = negative control serum reacted with His6-tagged VP26.

mation was carried out with competent $E$. coli $\mathrm{DH} 5 \alpha$ cells for the purpose of screening. The positive colonies were identified by PCR and restriction digestion (fig. 4). After confirmation, a positive clone was submitted to DNA sequencing and the result confirmed that the UL35 gene was in frame with the N-terminal His6 tag within the pET-32a $(+)$ multiple cloning sites (data not shown).

\section{Expression of the Recombinant Protein}

After sequence confirmation, the recombinant plasmid pET-32a(+)/UL35 was introduced into the expression host $E$. coli BL21(DE3). A positive transformant was used for the subsequent induction. Initially, the induction of His6-tagged VP26 expression was carried out at $37^{\circ}$ for $4 \mathrm{~h}$ by the addition of $1.0 \mathrm{mM}$ IPTG. A distinct band of approximately $33 \mathrm{kDa}$ of molecular weight, corresponding to the expected size of the His6-tagged VP26 fusion protein (fig. 5a, lane 9), was observed. This result confirmed that the ORF was properly expressed in the transformed E. coli BL21 (DE3) cells. Expressed protein was not detected in the negative control E. coli BL21 (DE3) cells (fig. 5a, lane 3) nor was it found without induction of $E$. coli BL21 (DE3) cells transformed with the pET$32 \mathrm{a}(+)$ vector (fig. $5 \mathrm{a}$, lane 1 ). Analysis of the densitometry scan of the $12 \%$ SDS-PAGE gel showed that the IPTGinduced band constituted approximately $24 \%$ of the total proteins in the induced cell extract (data not shown).

The relative distribution of the expressed recombinant protein in the soluble and insoluble fractions of the supernatant and the pellet (see Materials and Methods) of the cell lysate was examined after sonication. The recombinant protein was predominantly expressed in the insoluble fraction, in the form of inclusion bodies (fig. $5 \mathrm{a}$, lanes 5, 7 and 9), indicating that little or no soluble proteins are formed. We then tried to optimize the expression conditions as described in Materials and Methods by utilization of different durations of induction, concentrations of IPTG and induction temperatures. The optimal induction of His6-tagged VP26 protein expression was obtained by growth in the presence of $1.0 \mathrm{~mm}$ IPTG (fig. 5b, lane 6) for $5 \mathrm{~h}$ (fig. $5 \mathrm{c}$, lane 6) at $34^{\circ}$ (fig. 5a, lane 7 ).

\section{Purification of the Recombinant Protein}

Generally, high-level expression of recombinant proteins in E. coli often results in the formation of insoluble and inactive aggregate known as inclusion bodies [29, 30]. They develop as a result of misfolding or partial folding of polypeptides with exposed hydrophobic patches and the consequent intermolecular interactions [31]. Therefore, purified inclusion bodies must be resolubilized by strong denaturants, such as $6 \mathrm{M}$ guanidine hydrochloride or $8 \mathrm{M}$ urea, which promote the disruption of intermolecular interactions and complete unfolding of the protein $[32,33]$. The denaturation solution is removed by dilution or a buffer exchange step [34, 35], which permits renaturation of the proteins.

Histidine tags have become common fusion partners for recombinant proteins to facilitate purification using IMAC. For purification of the recombinant His6-tagged VP26 fusion protein from the insoluble fraction, the dissolved protein (inclusion bodies) was used as starting material and subjected to His tag purification using a single chromatographic step of IMAC on $\mathrm{Ni}^{2+}$-NTA agarose, as described. After elution with IMAC buffer containing $8 \mathrm{M}$ urea and dialysis against $\mathrm{PBS}$ containing progressively lower concentrations of urea $(4,2$, and $0 \mathrm{M})$, a clear band corresponding to a molecular mass of about $33 \mathrm{kDa}$ was seen on the SDS-PAGE gel following Coomassie blue staining (fig. 6, lane 5). This procedure allowed to harvest $\sim 620 \mathrm{mg}$ of nearly homogeneous protein (98\%, accord- 
Table 1. Purification of the recombinant His-tagged VP26 from $4 \mathrm{~g}$ of wet weight E. coli cells

\begin{tabular}{llllllll}
\hline Purification step & $\begin{array}{l}\text { Volume } \\
\mathrm{ml}\end{array}$ & $\begin{array}{l}\text { Total protein } \\
\mathrm{mg}\end{array}$ & $\begin{array}{l}\text { His-tagged } \\
\text { VP26, mg }\end{array}$ & $\begin{array}{l}\text { Protein concen- } \\
\text { tration }^{\mathrm{b}}, \mu \mathrm{g} / \mathrm{ml}\end{array}$ & $\begin{array}{l}\text { Purity } \\
\%\end{array}$ & $\begin{array}{l}\text { Purification } \\
\text { factor, fold }\end{array}$ & $\begin{array}{l}\text { Cumulative } \\
\text { yield, } \%\end{array}$ \\
\hline Crude extract $^{\mathrm{c}}$ & 10 & 54.75 & 13.14 & 1,314 & 24 & 1 & 100 \\
IMAC $^{\mathrm{d}}$ & 3 & 1.90 & 1.86 & 620 & 98 & 4 & 14 \\
\hline
\end{tabular}

a Total protein was isolated from 1 liter of culture medium after induction with $1.0 \mathrm{mM}$ IPTG at $34^{\circ}$ for $5 \mathrm{~h}$.

${ }^{b}$ Protein concentration indicates the concentration of His-tagged VP26. Protein concentrations were estimated by the Bradford method using BSA as standard.

${ }^{c}$ The pellets containing the insoluble fraction (crude extract) obtained from 1 liter of culture medium after centrifugation and sonication.

$\mathrm{d}$ The purified recombinant His-tagged VP26 using IMAC on $\mathrm{Ni}^{2+}$-NTA affinity resin.

ing to gel densitometry analysis) per liter of culture medium (1 liter bacterial cell culture produced about $4 \mathrm{~g}$ of wet weight cells in our study). The purification is summarized in table 1.

\section{Purification of the Antiserum and Antigenicity}

\section{Analysis of the Recombinant Protein}

After 4 injections had been given to 6 New Zealand white rabbits, the serum containing anti-His6-tagged VP26 polyclonal antibody with the stronger specificity was collected. The rabbit anti-His6-tagged VP26 IgG, with 55 and $22 \mathrm{kDa}$ of the heavy and light chains, was firstly precipitated by ammonium sulfate precipitation (fig. 7, lane 1) and then purified by ion exchange column chromatography (fig. 7, lane 2). Western blot analysis showed that the purified His6-tagged VP26 was recognized by the rabbit anti-His6-tagged VP26 IgG and showed a specific signal at $33 \mathrm{kDa}$, which is the expected size of the fusion protein (fig. 6, lane 6). Importantly, no positive signal was observed when using the negative control serum (fig. 6, lane 7), indicating that the recombinant protein induced an immunological response and that the antiserum had a high level of specificity. Based upon these results, this antiserum was deemed suitable to characterize the structure, molecular mechanism, and functional involvement of the VP26 protein in the DPV life cycle.

Previous studies of the herpes simplex virus (HSV) UL35 protein of the subfamily Alphaherpesvirinae have documented that the UL35 gene acts as the real late gene $\gamma_{2}$, which encodes a small nucleocapsid protein that is located on the hexon of the nucleocapsid. This protein interacts with the viral DNA of the nucleocapsid. It is nonessential for the formation of the viral capsid and viral propagation in cell culture, but it is essential for viral

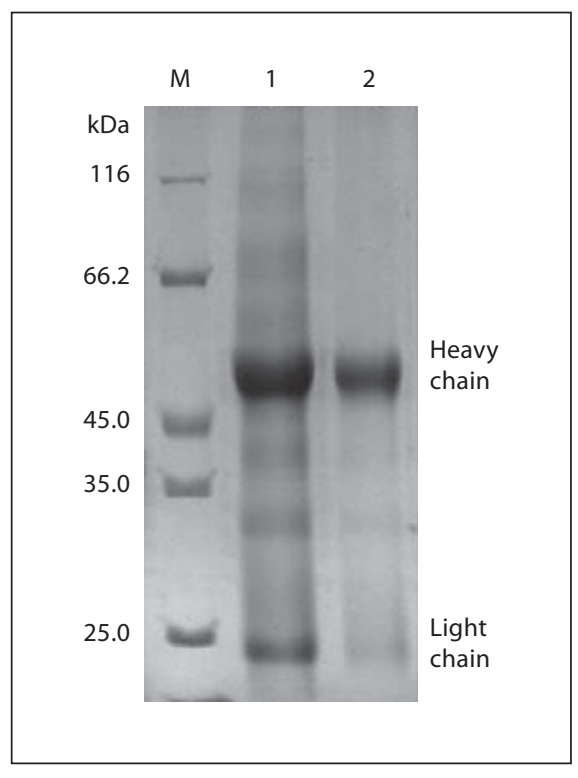

Fig. 7. SDS-PAGE analysis of the purified rabbit anti-His6-tagged VP26 IgG. M = Protein molecular weight marker; 1 = rabbit antiHis6-tagged VP26 IgG obtained by ammonium sulfate precipitation; 2 = rabbit anti-His6-tagged VP26 IgG obtained by ion exchange column chromatography.

replication in the nervous system. Furthermore, the absence of this protein will result in a 100 -fold reduced yield of infectious virus in the trigeminal ganglion [36-38]. This protein is located at the exterior of the icosahedral capsid, which indicates that VP26 may serve as a core that connects the capsid with the external tegument and envelope in the late stage of viral assembly [37]. The sites of this protein that are exposed on the outside of the capsid also reveal that VP26 is in a favorable position to couple 
the capsid and its functional ligand, such as tegument [39]. Similarly, research on the homolog of VP26 suggests that the smallest capsid protein, which is located at the most exterior region of the capsid, may play an important role in the tegumention and/or uncoating of the virion in the course of infection and in the regulation of the interaction between the capsid and tegument as well as cytoskeletal proteins [40]. Recent studies have also revealed that VP26 of HSV-1 associates with ribosomes and may regulate the host cell translation [41]. Based upon the important role played by HSV VP26 during HSV infection, we suggest that VP26 of DPV may play a similar role in the course of DPV infection. Importantly, the exact roles of DPV VP26 remain undefined.

\section{Conclusion}

In conclusion, the UL35 gene that encodes VP26 was amplified by PCR from the genome of the DPV CHv strain. It was cloned, and the recombinant protein was expressed and purified from E. coli. Western blot analyses suggest that the polyclonal antibody raised against the recombinant protein reacted with the purified recombinant protein, indicating that this specific antibody may serve as a good tool for future studies of VP26, e.g. analyses of subcellular localization, and may permit elucidation of the structure, molecular mechanism, and functional involvement of VP26 in the DPV life cycle.

\section{Acknowledgments}

The research was supported by grants from the National Natural Science Foundation of China (30771598), Changjiang Scholars and Innovative Research Team of the University (PCSIRT0848), the earmarked fund for the Modern Agroindustrial Technology Research System (2009-2013), the New Century Excellent Talents Program of the University (NCET-06-0818), the Scientific and Technological Innovation Major Project Funds of the University (706050), the Cultivation Fund of the Key Scientific and Technical Innovation Project, the Department of Education of the Sichuan Province (07ZZ028), and the Sichuan Province Basic Research Program (07JY029-016/17).

\section{References}

1 Baudet AERF: Mortality in ducks in The Netherlands caused by a filtrable virus: fowl plague. Tijdschr Diergeneeskd 1923;50:455459.

2 Levine PP, Fabricant J: A hitherto-undescribed virus disease of ducks in North America. Cornell Vet 1950;40:71-86.

-3 Campagnolo ER, Banerjee M, Panigrahy B: An outbreak of duck viral enteritis (duck plague) in domestic Muscovy ducks (Cairina moschata domesticus) in Illinois. Avian Dis 2001;45:522-528.

-4 Plummer PJ, Alefantis T, Kaplan S, O’Connell P, Shawky S, Schat KA: Detection of duck enteritis virus by polymerase chain reaction. Avian Dis 1998;42:554-564.

5 Proctor SJ: Pathogenesis of duck plague in the bursa of Fabricius, thymus, and spleen. Am J Vet Res 1976;37:427-431.

6 Shawky S, Sandhu T, Shivaprasad HL: Pathogenicity of a low-virulence duck virus enteritis isolate with apparent immunosuppressive ability. Avian Dis 2000;44:590-599.

7 Converse KA, Kidd GA: Duck plague epizootics in the United States, 1967-1995. J Wild Dis 2001;37:347-357.

8 Jansen J: Duck plague. J Am Vet Med Assoc 1968;152:1009-1016.

9 Sandhu TS, Shawky SA: Duck Virus Enteritis (Duck Plague), ed 11, revised. Iowa, Iowa State University Press, 2003, pp 354-363.
10 Yin ZH, Liu JH: Animal Virology, ed 2, revised. Beijing, Science Press, 1997, pp $1073-$ 1077.

11 Gardner R, Wilkerson J, Johnson JC: Molecular characterization of the DNA of Anatid herpesvirus 1. Intervirology 1993;36:99112.

12 Kaleta EF: Herpesviruses of birds - a review. Avian Pathol 1990;19:193-211.

13 Shawky S, Schat KA: Latency sites and reactivation of duck enteritis virus. Avian Dis 2002;46:308-313.

14 Fauquet CM, Mayo MA, Maniloff J, Desselberger U, Ball LA: Virus Taxonomy: Eighth Report of the International Committee on Taxonomy of Viruses. San Diego, Elsevier, 2005.

15 Chen S, Han Z, Shao Y, Liu S, Kong X: Molecular characterization of the UL6 gene of duck enteritis virus (in Chinese). Bing Du Xue Bao 2006;22:391-396.

16 Liu SW, Chen SH, Li HX, Kong XG: Molecular characterization of the herpes simplex virus 1 (HSV-1) homologues, UL25 to UL30, in duck enteritis virus (DEV). Gene 2007;401: 88-96.

17 Hansen WR, Brown SE, Nashold SW, Knudson DL: Identification of duck plague virus by polymerase chain reaction. Avian Dis 1999;43:106-115.
8 Cheng AC, Wang MS, Wen M, Zhou WG, Guo YF, Jia RY, Xu C, Yuan GP, Liu YC: Construction of duck enteritis virus gene libraries and discovery, cloning and identification of viral nucleocapsid protein gene. High Technol Lett 2006;16:948-953.

19 Mierendorf R, Yeager K, Novy R: The pET system: your choice for expression. Innovations 1994;1:1-3.

20 Studier FW, Rosenberg AH, Dunn JJ, Dubendorff JW: Use of T7 RNA polymerase to direct expression of cloned genes. Methods Enzymol 1990;185:60-89.

21 Studier FW, Moffatt BA: Use of bacteriophage T7 RNA polymerase to direct selective high-level expression of cloned genes. J Mol Biol 1986;189:113-130.

22 Li H, Liu S, Kong X: Characterization of the genes encoding UL24, TK and gH proteins from duck enteritis virus (DEV): a proof for the classification of DEV. Virus Genes 2006; 33:221-227.

23 Sambrook J, Russell D: Molecular Cloning A Laboratory Manual. Cold Spring Harbor, Cold Spring Harbor Laboratory Press, 2001.

24 Birnboim HC: A rapid alkaline extraction method for the isolation of plasmid DNA. Methods Enzymol 1983;100:243-255.

25 Laemmli UK: Cleavage of structural proteins during the assembly of the head of bacteriophage T4. Nature 1970;227:680-685. 
-26 Bradford MM: A rapid and sensitive method for the quantitation of microgram quantities of protein utilizing the principle of proteindye binding. Anal Biochem 1976;72:248254.

-27 Towbin H, Staehelin T, Gordin J: Electrophoretic transfer of proteins from polyacrylamide gels to nitrocellulose sheets: procedure and some applications. Proc Natl Acad Sci USA 1979;76:4350-4354.

-28 Brown CM, Stockwell PA, Trotman CAN: The signal for the termination of protein synthesis in prokaryotes. Nucleic Acids Res 1990;18:2079-2086.

29 Schein CH: Solubility as a function of protein structure and solvent components. Biotechnology 1990;8:308-317.

30 Oneda H, Inouye K: Refolding and recovery of recombinant human matrix metalloproteinase 7 (matrilysin) from inclusion bodies expressed by Escherichia coli. J Biochem 1999;126:905-911.
31 Kopito RR: Aggresomes, inclusion bodies and protein aggregation. Trends Cell Biol 2000;10:524-530.

32 Clark EDB: Refolding of recombinant proteins. Curr Opin Biotechnol 1998;9:157163.

33 Middelberg AP: Preparative protein refolding. Trends Biotechnol 2002;20:437-443.

34 Goldberg ME, Rudolph R, Jaenicke R: A kinetic study of the competition between renaturation and aggregation during the refolding of denatured-reduced egg white lysozyme. Biochemistry 1991;30:2790-2797.

35 Yon JM: The specificity of protein aggregation. Nat Biotechnol 1996;14:1231.

36 McNabb DS, Courtney RJ: Identification and characterization of the herpes simplex virus type 1 virion protein encoded by the UL35 open reading frame. J Virol 1992;66: 2653-2663.

37 Booy FP, Trus BL, Newcomb WW, Brown JC, Conway JF, Steven AC: Finding a needle in a haystack: detection of a small protein (the $12-\mathrm{kDa}$ VP26) in a large complex (the 200 MDa capsid of herpes simplex virus). Proc Natl Acad Sci USA 1994;91:5652-5656.
38 Desai P, DeLuca NA, Person S: Herpes simplex virus type 1 VP26 is not essential for replication in cell culture but influences production of infectious virus in the nervous system of infected mice. Virology 1998;247: 115-124.

39 Booy FP, Trus BL, Davison AJ, Steven AC: The capsid architecture of channel catfish virus, an evolutionarily distant herpesvirus, is largely conserved in the absence of discernible sequence homology with herpes simplex virus. Virology 1996;215:134-141.

40 Pierrette L, Yu XK, Ivo A, Bala C, Zhou ZH: Three-dimensional localization of pORF65 in Kaposi's sarcoma-associated herpesvirus capsid. J Virol 2003;77:4291-4297.

41 Greco A, Bienvenut W, Sanchez JC, Kindbeiter K, Hochstrasser D, Madjar JJ, Diaz JJ: Identification of ribosome-associated viral and cellular basic proteins during the course of infection with herpes simplex virus type 1. Proteomics 2001;1:545-549. 